\title{
Synthesis and evaluation of novel 17-indazole androstene derivatives designed as CYP17 inhibitors
}

\author{
Vânia M.A. Moreira ${ }^{a}$, Tadas S. Vasaitis ${ }^{b}$, \\ Vincent C.O. Njar ${ }^{b, * *}$, Jorge A.R. Salvador ${ }^{a, *}$ \\ a Laboratório de Química Farmacêutica, Faculdade de Farmácia, Universidade de Coimbra, \\ Rua do Norte, 3000-295 Coimbra, Portugal \\ b Department of Pharmacology \& Experimental Therapeutics, University of Maryland School of Medicine, \\ Baltimore, 655W Baltimore Street, Baltimore, MD 21201-1559, USA
}

\section{A R T I C L E I N F O}

\section{Article history:}

Received 4 July 2007

Received in revised form

20 July 2007

Accepted 9 August 2007

Published on line 15 August 2007

\section{A B S T R A C T}

A series of novel $1 \mathrm{H}$ - and $2 \mathrm{H}$-indazole derivatives of the commercially available dehydroepiandrosterone acetate have been synthesized and tested for inhibition of human cytochrome $17 \alpha$-hydroxylase- $\mathrm{C}_{17,20}$-lyase (CYP17), androgen receptor (AR) binding affinity, and cytotoxic potential against three prostate cancer (PC) cell lines.

() 2007 Elsevier Inc. All rights reserved.

Keywords:

Indazole

CYP17

Prostate cancer

Androgen receptor

PC cell lines

\section{Introduction}

CYP17 is an endoplasmic reticulum membrane-bound multifunctional enzyme that exhibits $17 \alpha$-hydroxylase and $\mathrm{C}_{17,20}$-lyase activities on a single active site, both of which are crucial for human physiology [1-5]. The hydroxylase activity is involved in the conversion of pregnenolone to $17 \alpha$-hydroxypregnenolone and progesterone to $17 \alpha$ hydroxyprogesterone whereas the lyase activity is responsible for the side-chain cleavage of these hydroxy derivatives to afford dehydroepiandrosterone (DHEA) and androstenedione (AD), respectively. DHEA and AD are androgen precursors and can be further metabolized in steroidogenic tissues to more potent androgens such as testosterone and dihydrotestosterone (DHT).

The testis and the adrenal cortex are the two sites thought to produce most of the androgenic steroids in humans. The testis are responsible for about $90-95 \%$ of circulating androgens whereas the adrenals account for the remaining $5-10 \%$ [6].

In the adult prostate, androgens act directly on epithelial cells to maintain structural and functional viability. The secretory epithelial cells express the AR and require chronic androgenic stimulation for survival and functional integrity.

\footnotetext{
* Corresponding author. Tel.: +351 239 859950; fax: +351 239827126.

** Corresponding author. Tel.: +1 410706 5885; fax: +1 4107060032

E-mail addresses: vnjar001@umaryland.edu (V.C.O. Njar), salvador@ci.uc.pt (J.A.R. Salvador). 0039-128X/\$ - see front matter @ 2007 Elsevier Inc. All rights reserved. doi:10.1016/j.steroids.2007.08.004
} 
Glandular involution occurs as a result of cell apoptosis when androgen levels drop below a threshold (as is the case in medical or surgical castration) [7].

Androgen deprivation as therapy for advanced PC was introduced by Huggins et al. in 1941 [8,9] and ever since it has been the mainstay for advanced PC treatment. At least $80 \%$ of the human prostate cancers show a favourable response to androgen deprivation as evidenced by the disappearance of symptoms or a decline of prostate specific antigen (PSA) levels [10,11]. However, relapses are seen invariably when tumors emerge as androgen-independent and apoptosis-resistant [7]. Mechanisms that may mediate this adaptation include AR amplification, AR mutation, alterations in the balance between transcriptional coactivators and corepressors, and activation of signal transduction pathways that by-pass the AR $[12,13]$. Gene amplification and amino acid substitutions in the AR are detected at a high frequency in recurrent tumors. These changes confer growth advantage to the tumor cells due to either hypersensitivity of AR to low, castrate-level androgens or a realignment of the receptor conformation, leading to altered ligand specificity that enables antiandrogens, adrenal androgens and non-androgen steroids to act agonistically to increase AR activity [7].

Enhanced intracellular conversion of adrenal androgens to testosterone and DHT has also been reported as an important mechanism for disease progression [14]. It may explain why the available AR antagonists do not have substantial activity against the androgen-independent tumor cells that emerge subsequent to androgen deprivation therapy, seeing that the AR antagonists will have a much lower affinity for the AR than the natural substrates. Inhibition of CYP17 is therefore a valuable approach for the treatment of androgen-dependent diseases such as PC as a means of inhibiting androgen biosynthesis both in the testis and adrenals. It should be noted that PC is a leading cause of mortality being the second most common cause of cancer-related death in both the USA and Australia (behind lung cancer), and the third most common cause of cancer-related death in the European Union (behind lung cancer and colorectal cancer) [15-17].

Several steroidal and non-steroidal compounds have been synthesized and evaluated as CYP17 inhibitors [18-23]. Out of these compounds, ketoconazole 1 (Fig. 1), an imidazole fungicide that has inhibitory activity towards CYP17 [24,25], has been used clinically in high dose ( $400 \mathrm{mg}$, every $8 \mathrm{~h}$ ) for the treatment of advanced PC [26-28]. However, the fact that it concomitantly inhibits other steroidal P450 enzymes causing significant side effects [29] has limited its use. A recent investigation of the efficacy of low dose ketoconazole $(200 \mathrm{mg}$, three times daily) found clinical benefit equal to high dose treatment, with a reduction in side effects [30]. Ketoconazole is still currently used alone or in combination with glucocorticoids as secondary hormonal therapy for hormone-refractory PC (HRPC) [31].

A common approach to the synthesis of potent steroidal inhibitors of CYP17 has been the design of substrate-like molecules bearing a heterocycle at the $\mathrm{C} 17$ position with privileged heteroatoms (N, S, O) which can interact as the sixth ligand with the heme iron of the enzyme. One of such compounds, abiraterone acetate 2 (Fig. 1), reported to be a very potent inhibitor of the enzyme [32], has successfully under-

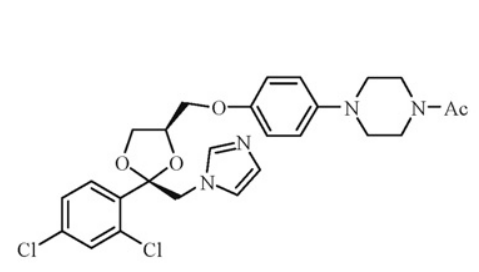

1

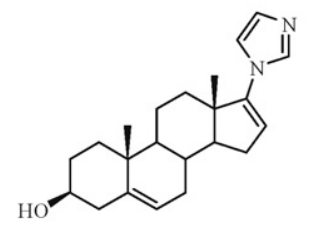

3

Fig. 1 - CYP17 inhibitors.
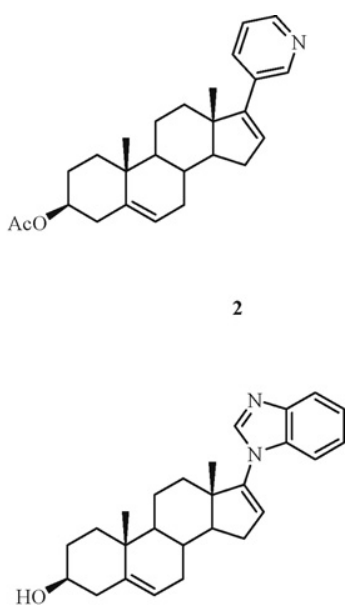

4 gone Phase I clinical trials for PC treatment $[33,34]$ and the first set of results of an open-label Phase II clinical trial have just been reported. Thus, 11 out of 18 patients have had PSA declines $\geq 50 \%$ at 3 months with 5 patients having a PSA decline $\geq 90 \%$ when $1000 \mathrm{mg}$ of the drug were administered orally once daily to chemotherapy-naive castration-resistant PC (CRPC) patients, resistant to luteinizing hormone-releasing hormone (LHRH) analogues, antiandrogens, and frequently diethylstilbestrol (DES) and steroids [35]

Another class of interesting steroidal inhibitors has been reported in which the azole group is attached to the C17 of the steroid nucleus through a nitrogen atom [36-38]. Both compound 3 (code named VN/85-1) (Fig. 1) and compound 4 (VN/124-1) potently inhibit CYP17. VN/124-1 has also been shown to have antiandrogenic properties against the androgen-dependent LAPC4 human prostate tumor xenograft, being actually more effective than castration in suppressing its growth [38].

Herein we report the synthesis and biological evaluation of novel 17-indazole androstene derivatives designed as CYP17 inhibitors. Other than their CYP17 inhibitory potential, their ability to bind to the AR, and cytotoxicity against three PC cell lines has also been evaluated.

\section{Experimental}

\subsection{Chemistry}

\subsubsection{General}

Dehydroepiandrosterone acetate, indazole, bis(triphenylphosphine)rhodium(I)carbonyl chloride, 1,3-bis(diphenylphosphino)propane, aluminum isopropoxide, and $\mathrm{N}$ methylpiperidone were obtained from Sigma-Aldrich Co. All solvents used were previously dried and purified according to standard procedures. For TLC analysis, Kieselgel $60 \mathrm{HF}_{254} /$ Kieselgel $60 \mathrm{G}$ was used. Melting points were determined using a BUCHI Melting Point B-540 apparatus and are uncorrected. IR spectra were obtained using a JASCO 
FT/IR-420 spectrophotometer. NMR spectra were obtained using a Brucker Digital NMR-Avance 300 apparatus or a Varian Inova 500 apparatus, in $\mathrm{CDCl}_{3}$ with $\mathrm{MeSi}_{4}$ as the internal standard. Mass spectra were recorded on a Finnigan Polaris Q GC/MS Benchtop Ion Trap mass spectrometer. HRMS were determined on a Bruker 12T APEX-Qe FTICR-MS with an Apollo II ion source and an Advion Triversa Nanomate system. Elemental analysis was carried out on a Fisons Instruments EA 1108 CHNS-O elemental analyzer.

\subsubsection{Synthesis of 17-(indazole) androstene derivatives}

2.1.2.1. 17-Chloroandrosta-5,16-dien-3 $\beta$-yl acetate (6) and 17chloro-16-formylandrosta-5,16-dien-3 $\beta$-yl acetate (7). Details of the synthesis of these compounds were reported previously $[37,39]$.

\subsubsection{16-Formyl-17-(1H-indazol-1-yl)androsta-5,16-dien-}

$3 \beta$-yl acetate (8) and 16-formyl-17-(2H-indazol-2-yl)androsta5,16-dien-3 $\beta$-yl acetate (9). A mixture of $7(2 \mathrm{~g}, 5.32 \mathrm{mmol})$, indazole ( $943 \mathrm{mg}, 7.98 \mathrm{mmol})$, and $\mathrm{K}_{2} \mathrm{CO}_{3}(2.2 \mathrm{~g}, 15.94 \mathrm{mmol})$ in dry DMF $(40 \mathrm{ml})$ was heated at $80^{\circ} \mathrm{C}$ under $\mathrm{N}_{2}$ atmosphere for $6 \mathrm{~h}$. The mixture was then concentrated under reduced pressure. Water $(60 \mathrm{ml})$ and dichloromethane $(200 \mathrm{ml})$ were added and the mixture was left under magnetic stirring for a couple of hours. The aqueous phase was extracted another two times with dichloromethane $(2 \times 50 \mathrm{ml})$. The organic phase was then washed with water $(60 \mathrm{ml})$, brine $(60 \mathrm{ml})$, dried with anhydrous $\mathrm{MgSO}_{4}$, filtered, and concentrated under reduced pressure to give a yellowish oil. This oil was subjected to flash chromatography with chloroform/petroleum ether $40-60^{\circ} \mathrm{C}$ (7:3) and afforded compound 8 (1.27 g; 52\%): m.p. (acetone/nhexane) $185-189^{\circ} \mathrm{C}$; IR $1248,163,1661,1721 \mathrm{~cm}^{-1} ;{ }^{1} \mathrm{H}$ NMR $\left(\mathrm{CDCl}_{3}, 300 \mathrm{MHz}\right): \delta 1.08$ (s, 3H, 18- $\left.\mathrm{H}_{3}\right), 1.27$ (s, 3H, 19- $\left.\mathrm{H}_{3}\right), 2.04$

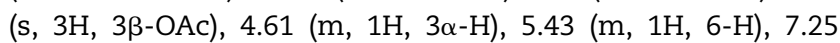
(m, 1H, aromatic $-\mathrm{H}), 7.45(\mathrm{~m}, 2 \mathrm{H}$, aromatic $-\mathrm{H}), 7.78(\mathrm{~m}, 1 \mathrm{H}$, aromatic-H), 8.24 (m, 1H, aromatic-H), 9.72 (s, 1H, CHO); EI-MS m/z (\%): 458 (12) M+ 398 (26), 225 (25), 185 (39), 157 (100), 143 (16), 91 (22), 77 (14); Anal. calcd. for $\mathrm{C}_{29} \mathrm{H}_{34} \mathrm{~N}_{2} \mathrm{O}_{3}$ : C 75.95, $\mathrm{H}$ 7.47, N 6.11, found: C 75.89, H 7.29, N 5.90. A second fraction afforded compound 9 (539 mg; 22\%): m.p. (acetone/n-hexane) 190-192 ${ }^{\circ} \mathrm{C}$; IR 1245, 1629, 1661, $1731 \mathrm{~cm}^{-1} ;{ }^{1} \mathrm{H} \mathrm{NMR}\left(\mathrm{CDCl}_{3}\right.$, $300 \mathrm{MHz}$ ): $\delta 1.09$ (s, 3H, 18- $\left.\mathrm{H}_{3}\right), 1.28\left(\mathrm{~s}, 3 \mathrm{H}, 19-\mathrm{H}_{3}\right), 2.04(\mathrm{~s}, 3 \mathrm{H}$, $3 \beta-\mathrm{OAc}), 4.62(\mathrm{~m}, 1 \mathrm{H}, 3 \alpha-\mathrm{H}), 5.43(\mathrm{~m}, 1 \mathrm{H}, 6-\mathrm{H}), 7.13(\mathrm{~m}, 1 \mathrm{H}$, aromatic- $\mathrm{H}), 7.34(\mathrm{~m}, 1 \mathrm{H}$, aromatic- $\mathrm{H}), 7.68(\mathrm{~m}, 1 \mathrm{H}$, aromatic$\mathrm{H}), 7.72(\mathrm{~m}, 1 \mathrm{H}$, aromatic- $\mathrm{H}), 8.19(\mathrm{~m}, 1 \mathrm{H}$, aromatic- $\mathrm{H}), 10.15$ (s, 1H, CHO); EI-MS m/z (\%): 458 (32) $\mathrm{M}^{+}, 398$ (74), 383 (48), 293 (24), 225 (56), 185 (54), 157 (100), 130 (20); Anal. calcd. for $\mathrm{C}_{29} \mathrm{H}_{34} \mathrm{~N}_{2} \mathrm{O}_{3}$ : C 75.95, H 7.47, N 6.11, found: C 76.02, H 7.53, N 5.88 .

2.1.2.3. 17-(1H-Indazol-1-yl)androsta-5,16-dien-3 $\beta$-yl acetate (10). A mixture of bis(triphenylphosphine)rhodium(I) carbonyl chloride (325.4 mg, $0.47 \mathrm{mmol})$ and 1,3bis(diphenylphosphino)propane $(420.7 \mathrm{mg}, 1.02 \mathrm{mmol})$ in dry xylenes $(95 \mathrm{ml})$ was stirred at $80^{\circ} \mathrm{C}$ under $\mathrm{N}_{2}$ for $15 \mathrm{~min}$ when a fine yellow precipitate formed. Compound 8 (1.2 g, $2.62 \mathrm{mmol}$ ) was added, and the mixture was refluxed under $\mathrm{N}_{2}$ for 10 days, then cooled, and concentrated under reduced pressure. The resulting oil was dissolved in dichloromethane $(600 \mathrm{ml})$ and treated with charcoal. The organic phase was washed with water $(60 \mathrm{ml})$, dried with anhydrous $\mathrm{MgSO}_{4}$, filtered, and concentrated under reduced pressure to give a yellowish oil. This oil was subjected to flash chromatography with chloroform/petroleum ether $40-60^{\circ} \mathrm{C}(7: 3)$ to give compound 10 (700 mg; 62\%): m.p. (acetonitrile/THF) $154-156^{\circ} \mathrm{C}$; IR 1241, 1620, $1728 \mathrm{~cm}^{-1} ;{ }^{1} \mathrm{H} \mathrm{NMR}\left(\mathrm{CDCl}_{3}, 300 \mathrm{MHz}\right.$ ): $\delta 1.09$ (s, $\left.3 \mathrm{H}, 18-\mathrm{H}_{3}\right), 1.18\left(\mathrm{~s}, 3 \mathrm{H}, 19-\mathrm{H}_{3}\right), 2.04(\mathrm{~s}, 3 \mathrm{H}, 3 \beta-\mathrm{OAc}), 4.61(\mathrm{~m}$, $1 \mathrm{H}, 3 \alpha-\mathrm{H}), 5.43(\mathrm{~m}, 1 \mathrm{H}, 6-\mathrm{H}), 5.86(\mathrm{~m}, 1 \mathrm{H}, 16-\mathrm{H}), 7.18(\mathrm{~m}, 1 \mathrm{H}$, aromatic- $\mathrm{H}), 7.39(\mathrm{~m}, 1 \mathrm{H}$, aromatic- $\mathrm{H}), 7.64(\mathrm{~m}, 1 \mathrm{H}$, aromatic$\mathrm{H}), 7.74(\mathrm{~m}, 1 \mathrm{H}$; aromatic- $\mathrm{H}), 8.07(\mathrm{~m}, 1 \mathrm{H}$, aromatic- $\mathrm{H}) ;{ }^{13} \mathrm{C}$ NMR (CDCl, $75 \mathrm{MHz}$ ): $\delta 124.3$ (C3a), 139.9 (C7a), 140.1 (C5), 150.6 (C17), 170.5 ( $\left.\mathrm{CH}_{3} \mathrm{CO}\right)$; EI-MS m/z (\%): 430 (20) $\mathrm{M}^{+}, 370$ (100), 355 (40), 195 (26), 157 (85), 144 (32), 119 (28), 91 (38); Anal. calcd. for $\mathrm{C}_{28} \mathrm{H}_{34} \mathrm{~N}_{2} \mathrm{O}_{2}$ : C 78.1, H 7.96, N 6.51, found: C 78.40, $\mathrm{H}$ $7.60, \mathrm{~N} 6.36$.

2.1.2.4. 17-(1H-Indazol-1-yl)androsta-5,16-dien-3 $\beta$-ol Compound 10 ( $400 \mathrm{mg} ; 0.93 \mathrm{mmol}$ ) was dissolved in methanol $(7.5 \mathrm{ml})$ at room temperature under $\mathrm{Ar} . \mathrm{KOH}(10 \%)$ in methanol $(2.5 \mathrm{ml})$ was added and the mixture was left under magnetic stirring for $1.5 \mathrm{~h}$. After this time the mixture was concentrated under reduced pressure. Dichloromethane $(150 \mathrm{ml})$ and water $(20 \mathrm{ml})$ were added, and left to agitate for a couple more hours. The aqueous phase was extracted with dichloromethane $(2 \times 100 \mathrm{ml})$. The organic phase was then washed with water $(20 \mathrm{ml})$, dried with anhydrous $\mathrm{MgSO}_{4}$, filtered, and evaporated to dryness to give compound 11 (297.1 mg; 82\%): m.p. (acetone) 189-191 ${ }^{\circ} \mathrm{C}$; IR 1625, $3257 \mathrm{~cm}^{-1}$; ${ }^{1} \mathrm{H}$ NMR ( $\mathrm{CDCl}_{3}, 300 \mathrm{MHz}$ ): $\delta 1.08\left(\mathrm{~s}, 3 \mathrm{H}, 18-\mathrm{H}_{3}\right), 1.18(\mathrm{~s}, 3 \mathrm{H}$, $\left.19-\mathrm{H}_{3}\right), 3.55(\mathrm{~m}, 1 \mathrm{H}, 3 \alpha-\mathrm{H}), 5.41(\mathrm{~m}, 1 \mathrm{H}, 6-\mathrm{H}), 5.86(\mathrm{~m}, 1 \mathrm{H}$, $16-\mathrm{H}), 7.18(\mathrm{~m}, 1 \mathrm{H}$, aromatic- $\mathrm{H}), 7.39(\mathrm{~m}, 1 \mathrm{H}$, aromatic- $\mathrm{H}), 7.64$ $(\mathrm{m}, 1 \mathrm{H}$, aromatic- $\mathrm{H}), 7.74(\mathrm{~m}, 1 \mathrm{H}$; aromatic- $\mathrm{H}), 8.07(\mathrm{~m}, 1 \mathrm{H}$,

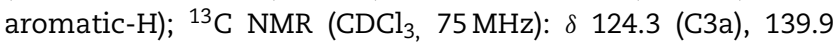
(C7a), 141.0 (C5), 150.6 (C17); EI-MS m/z (\%): 388 (100) M+, 373 (35), 237 (29), 195 (24), 181 (14), 157 (26), 119 (22), 91 (17); Anal. calcd. for $\mathrm{C}_{26} \mathrm{H}_{32} \mathrm{~N}_{2} \mathrm{O}$ : C 80.37, H 8.3, N 7.21, found: C 80.46, H 8.07, N 7.0.

2.1.2.5. 17-(1H-Indazol-1-yl)androsta-4,16-dien-3-one (12). A mixture of 11 ( $470 \mathrm{mg} ; 1.21 \mathrm{mmol}), \mathrm{N}$-methylpiperidone $(1.7 \mathrm{ml})$, and toluene $(28 \mathrm{ml})$ was distilled off ca. $10 \mathrm{ml}$. Aluminum isopropoxide ( $453 \mathrm{mg} ; 2.22 \mathrm{mmol}$ ) was then added, and the mixture was refluxed under $\mathrm{N}_{2}$ for $5 \mathrm{~h}$. The mixture was then concentrated under reduced pressure. Ethyl acetate $(20 \mathrm{ml})$ and water $(50 \mathrm{ml})$ were added and the mixture was left under magnetic stirring for a couple of hours. The aqueous phase was further extracted with ethyl acetate $(2 \times 100 \mathrm{ml})$. The organic phase was washed with $5 \% \mathrm{HCl}(50 \mathrm{ml}), 10 \%$ $\mathrm{NaHCO}_{3}(50 \mathrm{ml})$, and water $(50 \mathrm{ml})$, dried with anhydrous $\mathrm{MgSO}_{4}$, filtered, and evaporated to dryness to afford compound 12 (390 mg; 83\%): m.p. (acetone/n-hexane) $196-197^{\circ} \mathrm{C}$; IR 1621, $1672 \mathrm{~cm}^{-1} ;{ }^{1} \mathrm{H}$ NMR $\left(\mathrm{CDCl}_{3}, 300 \mathrm{MHz}\right): \delta 1.20(\mathrm{~s}, 3 \mathrm{H}$, 18- $\mathrm{H}_{3}$ ), 1.24 (s, 3H, 19- $\mathrm{H}_{3}$ ), 5.76 (brs, $\left.1 \mathrm{H}, 4-\mathrm{H}\right), 5.85$ (m, 1H, 16$\mathrm{H}), 7.17(\mathrm{~m}, 1 \mathrm{H}$, aromatic- $\mathrm{H}), 7.40(\mathrm{~m}, 1 \mathrm{H}$, aromatic-H), 7.64 $(\mathrm{m}, 1 \mathrm{H}$, aromatic- $\mathrm{H}), 7.74(\mathrm{~m}, 1 \mathrm{H}$, aromatic- $\mathrm{H}), 8.07(\mathrm{~m}, 1 \mathrm{H}$,

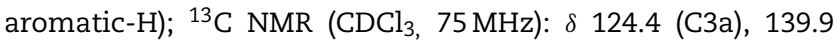
(C7a), 150.4 (C17), 171.0 (C5), 199.5 (C3); EI-MS m/z (\%): 386 (100) $\mathrm{M}^{+}, 371$ (75), 253 (22), 211 (16), 183 (21), 157 (30), 119 (18), 81 (14); HRMS calcd $387.2431\left(\mathrm{C}_{26} \mathrm{H}_{30} \mathrm{~N}_{2} \mathrm{OH}^{+}\right)$, found 387. 2435 . 
2.1.2.6. 17-(2H-Indazol-2-yl)androsta-5,16-dien-3 $\beta$-yl acetate (13). The method followed that described for compound 10 but using compound 9 (700 $\mathrm{mg} ; 1.53 \mathrm{mmol}$ ). The resulting oil was subjected to flash chromatography with chloroform/petroleum ether $40-60^{\circ} \mathrm{C}(7: 3)$ which afforded compound 13 (308 mg; 47\%): m.p. (acetone) $144-146^{\circ} \mathrm{C}$; IR 1243, 1620, $1728 \mathrm{~cm}^{-1} ;{ }^{1} \mathrm{H}$ NMR $\left(\mathrm{CDCl}_{3}, 300 \mathrm{MHz}\right): \delta 1.09$ (s, 3H, 18- $\left.\mathrm{H}_{3}\right)$, $1.19\left(\mathrm{~s}, 3 \mathrm{H}, 19-\mathrm{H}_{3}\right), 2.04(\mathrm{~s}, 3 \mathrm{H}, 3 \beta-\mathrm{OAc}), 4.62(\mathrm{~m}, 1 \mathrm{H}, 3 \alpha-\mathrm{H})$, $5.43(\mathrm{~m}, 1 \mathrm{H}, 6-\mathrm{H}), 6.14(\mathrm{~m}, 1 \mathrm{H}, 16-\mathrm{H}), 7.06(\mathrm{~m}, 1 \mathrm{H}$, aromatic$\mathrm{H}), 7.27(\mathrm{~m}, 1 \mathrm{H}$, aromatic- $\mathrm{H}), 7.64(\mathrm{~m}, 1 \mathrm{H}$, aromatic- $\mathrm{H}), 7.71(\mathrm{~m}$, $1 \mathrm{H}$; aromatic-H), $8.11(\mathrm{~m}, 1 \mathrm{H}$, aromatic- $\mathrm{H}) ;{ }^{13} \mathrm{C} \mathrm{NMR}\left(\mathrm{CDCl}_{3}\right.$, $75 \mathrm{MHz}$ ): $\delta 121.7$ (C3a), 140.0 (C5), 148.9 (C7a), 151.7 (C17), $170.5\left(\mathrm{CH}_{3} \mathrm{CO}\right) ; \mathrm{EI}-\mathrm{MS} \mathrm{m} / \mathrm{z}$ (\%): 430 (14) $\mathrm{M}^{+}, 370$ (100), 355 (56), 209 (18), 195 (24), 157 (57), 105 (16), 91 (13); Anal. calcd. for $\mathrm{C}_{28} \mathrm{H}_{34} \mathrm{~N}_{2} \mathrm{O}_{2}$ : C 78.1, H 7.96, N 6.51, found: C 78.5, H 7.6, N 6.2.

2.1.2.7. 17-(2H-Indazol-2-yl)androsta-5,16-dien-3 $\beta$-ol (14). The method followed that described for compound 11 but using compound 13 ( $255.8 \mathrm{mg} ; 0.59 \mathrm{mmol}$ ) to afford compound 14 (216.8 mg; 94\%): m.p. (acetonitrile/THF) 224-226 ${ }^{\circ} \mathrm{C}$; IR 1629 , $3352 \mathrm{~cm}^{-1} ;{ }^{1} \mathrm{H} \mathrm{NMR}\left(\mathrm{CDCl}_{3}, 300 \mathrm{MHz}\right): \delta 1.08$ (s, 3H, 18- $\left.\mathrm{H}_{3}\right), 1.19$ (s, 3H, 19- $\left.\mathrm{H}_{3}\right), 3.55(\mathrm{~m}, 1 \mathrm{H}, 3 \alpha-\mathrm{H}), 5.40(\mathrm{~m}, 1 \mathrm{H}, 6-\mathrm{H}), 6.17(\mathrm{~m}$, $1 \mathrm{H}, 16-\mathrm{H}), 7.07$ (m, 1H, aromatic- $\mathrm{H}), 7.27$ (m, 1H, aromatic- $\mathrm{H})$, $7.64(\mathrm{~m}, 1 \mathrm{H}$, aromatic- $\mathrm{H}), 7.71(\mathrm{~m}, 1 \mathrm{H}$; aromatic- $\mathrm{H}), 8.11(\mathrm{~m}$, $1 \mathrm{H}$, aromatic-H); ${ }^{13} \mathrm{C} \mathrm{NMR}\left(\mathrm{CDCl}_{3}, 75 \mathrm{MHz}\right): \delta 121.7$ (C3a), 141.2 (C5), 148.9 (C7a), 151.70 (C17); EI-MS m/z (\%): 388 (100) M+, 373 (68), 369 (23), 223 (22), 209 (26), 195 (32), 181 (18), 157 (86); Anal. calcd. for $\mathrm{C}_{26} \mathrm{H}_{32} \mathrm{~N}_{2} \mathrm{O}$ : C 80.37, $\mathrm{H} \mathrm{8.3,} \mathrm{N} 7.21$, found: $\mathrm{C} 80.2, \mathrm{H}$ 8.16, N 7.15.

\subsubsection{17-(2H-Indazol-2-yl)androsta-4,16-dien-3-one}

The method followed that described for compound 12 but using compound 14 (450 mg; $1.16 \mathrm{mmol}$ ) to afford compound 15 (370 mg; 83\%): m.p. (acetone) $169-172{ }^{\circ} \mathrm{C}$; IR 1629 , $1674 \mathrm{~cm}^{-1} ;{ }^{1} \mathrm{H} \mathrm{NMR}\left(\mathrm{CDCl}_{3}, 300 \mathrm{MHz}\right): \delta 1.21\left(\mathrm{~s}, 3 \mathrm{H}, 18-\mathrm{H}_{3}\right)$, 1.25 (s, 3H, 19- $\left.\mathrm{H}_{3}\right), 5.77$ (brs, 1H, 4-H), 6.14 (m, 1H, 16-H), $7.07(\mathrm{~m}, 1 \mathrm{H}$, aromatic-H), $7.27(\mathrm{~m}, 1 \mathrm{H}$, aromatic- $\mathrm{H}), 7.64$ $(\mathrm{m}, 1 \mathrm{H}$, aromatic- $\mathrm{H}), 7.72(\mathrm{~m}, 1 \mathrm{H}$; aromatic- $\mathrm{H}), 8.11(\mathrm{~m}, 1 \mathrm{H}$,

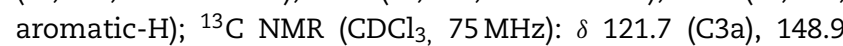
(C7a), 151.6 (C17), 170.6 (C5), 199.4 (C3); EI-MS m/z (\%): 386 (72) M+, 371 (62), 223 (39), 195 (36), 157 (100), 145 (25), 119 (35), 91 (42); HRMS calcd $387.2431\left(\mathrm{C}_{26} \mathrm{H}_{30} \mathrm{~N}_{2} \mathrm{OH}^{+}\right)$, found 387.2431 .

\subsection{Biology}

\subsubsection{General}

The human PC cell lines LNCaP and PC-3 were obtained from the American Type Culture Collection (Rockville, MD). 293T cells were the gift of Dr. Yun Qiu (UMB, Maryland), and LAPC4 cells were provided by Dr. Charles L. Sawyers (UCLA School of Medicine).

RPMI 1640 medium, Dulbecco's Modified Eagle Medium (DMEM), Dulbecco's Phosphate Buffered Saline (DPBS), trypsin/EDTA (0.25\%/0.02\%), and penicillin/streptomycin (P/S) were obtained from Gibco-BRL. Fetal Bovine Serum (FBS), charcoal-stripped serum (CSS), and trypsin/versene were obtained from Biofluids Inc. Poly-L-lysine, triamcinolone acetonide, ketoconazole, DHT, and MTT powder were obtained from Sigma-Aldrich Co. Casodex was kindly provided by Astra-Zeneca Inc. Scintiverse BD Cocktail (Scintanalyzed) fluid was obtained from Fisher Scientific. VN/85-1 was prepared as previously reported [37].

The synthetic androgen methyltrinolone $\left[{ }^{3} \mathrm{H}\right] \mathrm{R} 1881$, with a specific activity of $72 \mathrm{Ci} / \mathrm{mmol}$, was purchased from PerkinElmer. [21- $\left.{ }^{3} \mathrm{H}_{3}\right]-17 \alpha$-hydroxypregnenolone, with a specific activity of $13.61 \mu \mathrm{Ci} / \mu \mathrm{mol}$, was prepared as described by Akhtar et al. [40].

The calcium phosphate transfection kit was purchased from Promega (Promega Profection Mammalian Transfection System). Tox-2 kit (XTT based) was purchased from Sigma-Aldrich Co.

293T and 293T-CYP17 cells were routinely maintained in DMEM supplemented with $10 \%$ FBS and $1 \% \mathrm{P} / \mathrm{S}$ solution. LNCaP and PC-3 cells were grown in RPMI 1640 medium supplemented with $10 \% \mathrm{FBS}$ and $1 \% \mathrm{P} / \mathrm{S}$ solution. LAPC4 cells were grown in RPMI supplemented with 15\% FBS, 1\% P/S solution, and $10 \mathrm{nM}$ DHT.

The $p$ CDNA3Hmod17(His) ${ }_{4}$ construct was designed as previously reported [41].

Radioactivity measurements were performed in a Tri-carb 2100 TR liquid scintillation analyzer. Absorbance and luminescence measurements were made using a Victor 1420 Multilabel counter.

\subsubsection{In vitro CYP17 assay ( $C_{17,20}$-lyase activity)}

The in vitro $C_{17,20}$-lyase inhibitory activities of the compounds were evaluated using the acetic acid releasing assay (AARA) [37,38,41-49] with $293 \mathrm{~T}$ cells that were transfected with the pCDNA3Hmod17(His) 4 construct using the calcium phosphate method (Promega Profection Mammalian Transfection System), to express the human enzyme.

Briefly, $100 \mathrm{~mm}$ plates were coated with poly-L-lysine $(0.05 \mathrm{mg} / \mathrm{ml})$ for $30 \mathrm{~min}$, rinsed twice with sterilized distilled water, and allowed to dry for $2 \mathrm{~h}$. 293T cells were then plated in DMEM at a density sufficient for achieving approximately $60 \%$ confluency on the following day, for transfection. Three hours prior to transfection the DMEM was renewed on the plate. On a small eppendorf flask, $10 \mu \mathrm{g}$ of $p$ CDNA3Hmod17(His) 4 were added to sterile, deionized water and vortexed briefly. A $2 \mathrm{M}$ $\mathrm{CaCl}_{2}$ solution $(62 \mu \mathrm{l})$ was added to bring the final volume up to $500 \mu \mathrm{l}$. This mixture was added drop-wise with light vortex to $500 \mu \mathrm{l}$ of HEPES solution and incubated at room temperature for $30 \mathrm{~min}$. The solution was vortexed again and dripped into the $100 \mathrm{~mm}$ plate. The medium was changed $18 \mathrm{~h}$ later and enzyme activity was assayed as described below $48 \mathrm{~h}$ after transfection.

293T-CYP17 cells were grown to $80 \%$ confluency and divided evenly in 6-well plates. On the following day, cells were washed with DPBS and incubated with clear DMEM (with $5 \%$ CSS and $1 \% \mathrm{P} / \mathrm{S}$ ) containing a saturating concentration of $\left[21-{ }^{3} \mathrm{H}_{3}\right] 17 \alpha$-hydroxypregnenolone. The test compounds were then added in the desired concentrations and the plates were left to incubate for $18 \mathrm{~h}$ at $37^{\circ} \mathrm{C}$. The steroids were extracted with $2 \mathrm{ml}$ of chloroform at $4{ }^{\circ} \mathrm{C}$. After $2 \mathrm{~h}$, the aqueous phase was collected and charcoal suspension was added to a $2.5 \%$ final concentration. Following a 30 -min incubation at $4{ }^{\circ} \mathrm{C}$, an aliquot of the aqueous supernatant was removed and radioactivity measured by liquid scintillation counting. 


\subsubsection{Competitive AR binding assay}

Competitive binding assays with the synthetic androgen methyltrienolone $\left[{ }^{3} \mathrm{H}\right] \mathrm{R} 1881$ were performed essentially as previously described $[50,51]$. LNCaP or LAPC4 cells were transferred to clear RPMI medium (with 5\% CSS and 1\% P/S) 3 days before the start of the experiment. 24-Well plates were coated with poly-L-lysine $(0.05 \mathrm{mg} / \mathrm{ml})$ for $30 \mathrm{~min}$, rinsed with sterilized distilled water, and dried for $2 \mathrm{~h}$. The cells were then plated $\left(2-3 \times 10^{5}\right.$ cells/well $)$ and allowed to attach. The following day the medium was replaced by clear RPMI (with
$1 \% \mathrm{P} / \mathrm{S}$ added) containing a saturation concentration (5 nM) of $\left[{ }^{3} \mathrm{H}\right] \mathrm{R} 1881$, triamcinolone acetonide $(1 \mu \mathrm{M})$, and the desired concentrations of the test compounds. Following a $2 \mathrm{~h}$ incubation period at $37^{\circ} \mathrm{C}$, cells were washed twice with ice-cold DPBS, and solubilized in DPBS containing 0.5\% SDS and $20 \%$ glycerol. Extracts were removed and cell associated radioactivity counted in a scintillation counter. All results represent an average of a minimum of three wells. To determine the $\mathrm{EC}_{50}$ values of the test compounds, a minimum of eight concentrations of each test compound was used. $\mathrm{EC}_{50}$ values were<smiles>CO[C@H]1CC[C@]2(C)C(=CCC3C4CCC(=O)C4(C)CCC32)C1</smiles><smiles>CC12CCC(O)CC1=CCC1C2CCC2(C)C(Cl)=C(C=O)CC12</smiles><smiles>CC1CCC2(C)C(=CCC3C2CCC2(C)C(Cl)=C(C=O)CC32)C1</smiles><smiles>COC1CCC2(C)C3=CCC4C(CCC3(C)C4n3ncc4ccccc43)C(C=O)CC2C1</smiles><smiles>CC1CCC2(C)C(=CCC3C2CCC2(C)C(n4cc5c(n4)CCC=C5)=C(C=O)CC32)C1</smiles><smiles>COC1CCC2(C)C(=CCC3C(C)CCC32)CCC1n1ncc2ccccc21</smiles><smiles>CO[C@H]1CC[C@]2(C)C(=CCC3C2CC[C@]2(C)C(n4cc5ccccc5n4)=CCC32)C1</smiles><smiles></smiles><smiles>CC12CCC(=O)C=C1CCC1C2CCC2(n3ncc4ccccc43)C=CCC12</smiles><smiles>CC12CC[C@H](O)CC1=CCC1C2CCC2(C)C1CCC21C(n2cc3ccccc3n2)CCC2C3CCC4=CC(=O)CCC4(C)C3CCC21C</smiles>

12 
determined by non-linear regression with Graphpad Prism software.

\subsubsection{Cell culture and viability assay}

To determine the effect of steroids and novel compounds on cell proliferation on LNCaP and LAPC4 cells, each cell type was transferred into clear RPMI medium (with 5\% CSS and 1\% P/S) 3 days prior to the start of the experiments. The cells were then plated on previously coated 96 -well plates $\left(2.5 \times 10^{3}\right.$ cell/well $)$ and after a $24 \mathrm{~h}$ attachment period, the medium was aspirated and replaced by new medium with the novel compounds (0.1-20 $\mu \mathrm{M})$. The medium was changed every 3 days and the number of viable cells was compared by XTT assay on the 7th day. Briefly, a $20 \%$ solution of XTT in clear medium was added to each of the wells in the plates and after a $4 \mathrm{~h}$ incubation period, the plates were read at $450 \mathrm{~nm}$ on a Victor 1420 Multilabel counter. All results represent the average of a minimum of three wells.

For PC-3 cells, $1.5 \times 10^{4}$ cells/well were plated in 24 -well plates in RPMI medium (with $10 \%$ FBS and $1 \% \mathrm{P} / \mathrm{S}$ ). After a $24 \mathrm{~h}$ attachment period, the cells were treated with the novel compounds $(0.1-20 \mu \mathrm{M})$. The medium was changed every 3 days and the number of viable cells was compared by MTT assay on the 7th day. Briefly, $0.5 \mathrm{mg} / \mathrm{ml} \mathrm{MTT}$ in clear RPMI medium (with $5 \%$ CSS and $1 \% \mathrm{P} / \mathrm{S}$ ) was added to each well and incubated at $37^{\circ} \mathrm{C}$ for $4 \mathrm{~h}$. Following incubation, the medium was aspirated completely with care taken not to disturb the formazan crystals. DMSO $(400 \mu \mathrm{l})$ was used to solubilize these crystals. After slight shaking, the plates were immediately read at $540 \mathrm{~nm}$ on a Victor 1420 Multilabel counter. All results represent an average of a minimum of three wells. To determine the $\mathrm{EC}_{50}$ values of the test compounds, PC-3 cells were incubated with a minimum of eight concentrations of each test compound. $\mathrm{EC}_{50}$ values were determined by non-linear regression with Graphpad Prism software.

\section{Results and discussion}

\subsection{Chemistry}

\subsubsection{Synthesis of 17-indazole androstene derivatives}

The synthesis of the new 17-indazole androstene derivatives is outlined in Scheme 1. It started with the Vilsmeier-Haack reaction of the commercially available dehydroepiandrosterone acetate 5 with phosphorous oxychloride $\left(\mathrm{POCl}_{3}\right)$ and dimethylformamide (DMF), as reported previously $[37,39]$. The major reaction product 17 -chloro-16-formylandrosta-5,16-diene-3 $\beta$ yl acetate 7 was then treated with indazole in the presence of $\mathrm{K}_{2} \mathrm{CO}_{3}$ and $\mathrm{DMF}$ at $80^{\circ} \mathrm{C}$, under $\mathrm{N}_{2}$ to afford a mixture of the $1 \mathrm{H}$ 8 and $2 \mathrm{H}$-indazole 9 substituted compounds which were separated by flash chromatography on silica gel. The $1 \mathrm{H}$-indazole derivative 8 was found to be the major reaction product being isolated in $52 \%$ yield (compound 9 was isolated in $22 \%$ yield).

Each of the obtained 17-indazole compounds 8 and 9 was separately decarbonylated to afford compounds 10 and 13 in 62 and 47\% yield, respectively. This decarbonylation was performed with in situ generated $\mathrm{Rh}(1,3-$ bis(diphenylphosphino)propane $)_{2}{ }^{+} \mathrm{Cl}^{-}$catalyst $\left[\mathrm{Rh}(\mathrm{dppp})_{2}{ }^{+}\right.$
$\mathrm{Cl}^{-}$] in refluxing xylenes $[37,52]$, after the use of both the Wilkinson catalyst $\left[\mathrm{RhCl}\left(\mathrm{PPh}_{3}\right)_{3}\right]$ and $10 \%$ palladium on activated charcoal, other known methods of decarbonylation, failed. Hydrolysis of the $3 \beta$-acetoxy group to obtain the corresponding 3 $\beta$-hydroxy derivatives 11 and 14 was achieved with $\mathrm{KOH}(10 \%)$ in methanol, in 82 and 94\% yield. Modified Oppenauer oxidation of substrates 11 and 14 using aluminum isopropoxide and $\mathrm{N}$-methylpiperidone afforded the final 3keto derivatives 12 and 15, again in good yields (83\% in both cases).

The peak pattern of the carbons seen on the ${ }^{13} \mathrm{C}$ NMR spectra of compounds 13-15 (2H-series) is consistent with data reported in the literature for $2 \mathrm{H}$-substituted compounds whereas for compounds 10-12 (1H-series) the spectra correlated well with that of $1 \mathrm{H}$-substituted derivatives [53]. In the $2 \mathrm{H}$-series, the two quaternary carbons of the indazole ring $\mathrm{C} 3 \mathrm{a}$ and $\mathrm{C} 7 \mathrm{a}$ are seen at ppm values of $121-123 \mathrm{ppm}$ and 148-153 ppm, respectively. For our compounds C3a was identified at $121 \mathrm{ppm}$ and $\mathrm{C} 7 \mathrm{a}$ at $148 \mathrm{ppm}$. The $1 \mathrm{H}$-series typically has $\mathrm{C} 3 \mathrm{a}$ at higher ppm values (123-126 ppm) whereas $\mathrm{C7a}$ is seen at lower ppm values of $137-148 \mathrm{ppm}$. Thus, in our $1 \mathrm{H}$-series we identified $\mathrm{C} 3 \mathrm{a}$ at $124 \mathrm{ppm}$ and $\mathrm{C} 7 \mathrm{a}$ at $139 \mathrm{ppm}$.

\subsection{Biology}

\subsubsection{CYP17 inhibition ( $C_{17,20}$-lyase)}

The AARA uses $\left[21-{ }^{3} \mathrm{H}_{3}\right] 17 \alpha$-hydroxypregnenolone as substrate and $\mathrm{C}_{17,20}$-lyase activity is measured by the amount of $\left[{ }^{3} \mathrm{H}\right]$ acetic acid released during the side-chain cleavage of the substrate to DHEA. This assay proved comparable in terms of accuracy and reliability to the previous HPLC procedures $[41,42]$. Moreover, kinetic analysis of CYP17 in human testicular microsomes showed that the $\mathrm{C}_{17,20}$-lyase activity is half that of the $17 \alpha$-hydroxylase activity thus implying that inhibition of the $C_{17,20}$-lyase activity will actually characterize the inhibition of the entire enzyme [41]. Human kidney 293T cells were chosen for the assay because they showed rapid growth

\begin{tabular}{|c|c|c|c|}
\hline Compound & $\begin{array}{l}\mathrm{C}_{17,20} \text {-lyase } \\
\mathrm{IC}_{50}{ }^{\mathrm{a}} 293 \mathrm{~T}\end{array}$ & $\begin{array}{c}\text { LNCaP } \\
\mathrm{EC}_{50} \mathrm{~b}(\mathrm{nM})\end{array}$ & $\begin{array}{c}\text { LAPC4 } \\
\mathrm{EC}_{50}{ }^{\mathrm{b}}(\mathrm{nM})\end{array}$ \\
\hline 10 & c & d & d \\
\hline 11 & c & $d$ & $\mathrm{~d}$ \\
\hline 12 & c & $d$ & 5000 \\
\hline 13 & c & $d$ & d \\
\hline 14 & c & d & $\mathrm{d}$ \\
\hline 15 & c & d & 5000 \\
\hline Ketoconazole & $49 \mathrm{nM}$ & NT & NT \\
\hline VN/85-1 & $1.29 \mathrm{nM}$ & NT & NT \\
\hline Casodex & $\mathrm{NT}^{\mathrm{e}}$ & 971 & 4500 \\
\hline \multicolumn{4}{|c|}{$\begin{array}{l}\text { a IC } 50 \text { is the concentration of inhibitor required to inhibit the } \\
\text { enzyme activity by } 50 \% \text {. } \\
\text { b } \\
\text { EC } 50 \text { is the concentration of compound needed for a } 50 \% \text { displace- } \\
\text { ment of }\left[{ }^{3} \mathrm{H}\right] \mathrm{R} 1881 \text { from the AR. } \\
\text { c Less than } 30 \% \text { effective at } 10 \mu \mathrm{M} \text {. } \\
\text { d Less than } 30 \% \text { binding at } 5 \mu \mathrm{M} \text {. } \\
\text { e NT = Not tested. }\end{array}$} \\
\hline
\end{tabular}


in culture medium and high transfection efficiency for the

The synthesized compounds were found not to inhibit $\mathrm{C}_{17,20}$-lyase significantly when compared to both ketoconazole and VN/85-1. Thus, all tested compounds (10-15) were less than $30 \%$ effective at $10 \mu \mathrm{M}$ whereas IC $_{50}$ values of 49 and $1.29 \mathrm{nM}$ were determined for ketoconazole and VN/85-1, respectively, under the same assay conditions (Table 1). Reasons that may account for this lack of inhibitory activity are human CYP17 plasmid.

Table 2 - Effect of the $2 \mathrm{H}$-indazole series on PC-3 cell proliferation

\begin{tabular}{lc} 
Compound & PC-3 EC $_{50}(\mu \mathrm{M})$ \\
\hline 13 & 5.4 \\
14 & 8.3 \\
15 & 1.9 \\
\hline
\end{tabular}
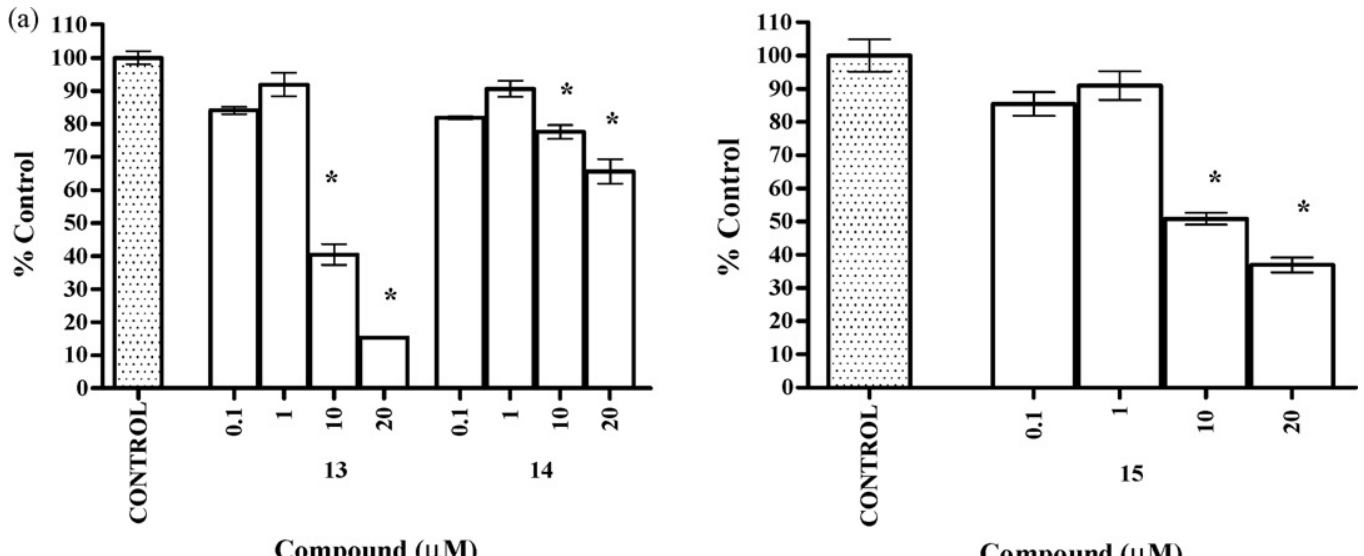

Compound $(\mu \mathrm{M})$
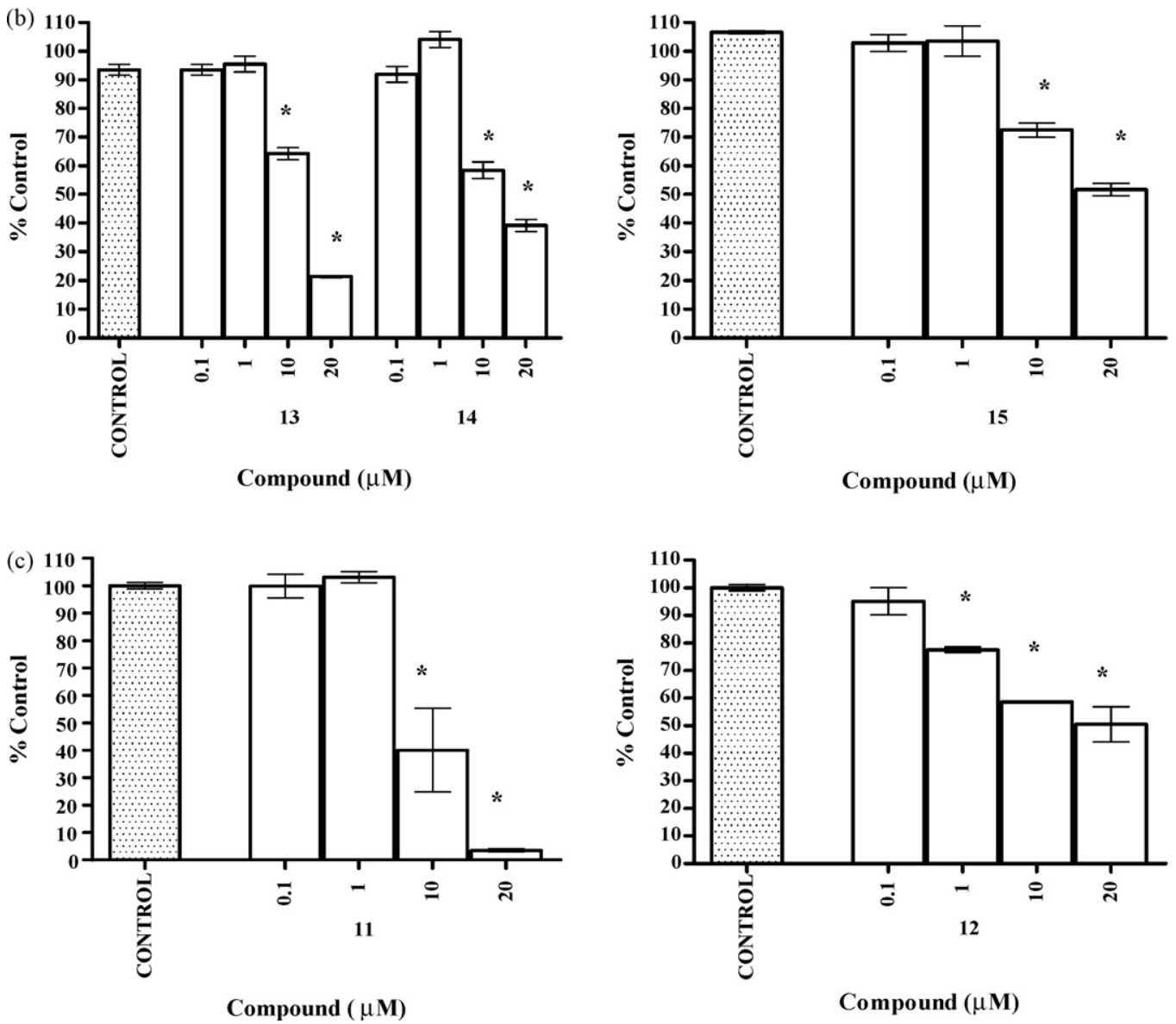

Fig. 2 - Effect of selected compounds on (a) LNCaP, (b) LAPC4, and (c) PC-3 cell proliferation. The percentage (compared to control) of growth inhibiton after 7 days of treatment was determined with the XTT (LNCaP and LAPC4) or MTT (PC-3) assay using 0.1-20 $\mu \mathrm{M}$ of compound, as described in Section 2. One-way ANOVA with a Dunnet Post Test was used to analyze the data: ${ }^{*} p<0.01$. 
the positioning of the $\mathrm{N}$ atoms in the heterocycle ring that may not permit good interaction with the enzyme's active site or even the bulkiness of the indazole ring.

\subsubsection{AR binding}

Following the observation that several compounds designed as CYP17 inhibitors have been shown to bind to the AR and interfere with its function $[37,38,45,54]$, we decided to determine if the synthesized indazole androstene derivatives could bind to the AR. LAPC4 and LNCaP cells were chosen which express the wild-type (wt-) and mutated receptor, respectively. Competitive binding of the compounds to the AR was evaluated using a saturating concentration of the radiolabeled androgen $\left[{ }^{3} \mathrm{H}\right] \mathrm{R} 1881$ in the presence of different concentrations of test compound.

Compounds 10,11, 13 and 14 showed less than $30 \%$ binding to both types of AR at $5 \mu \mathrm{M}$ (Table 1). However, compounds 12 and 15 , having the $\Delta^{4}$-3-ketone system in common, bound to the wt-AR with similar affinity when compared to Casodex, an antiandrogen currently used in PC treatment, showing an $\mathrm{EC}_{50}$ of $5 \mu \mathrm{M}$ (4.5 $\mu \mathrm{M}$ for Casodex).

\subsubsection{PC cell toxicity}

The potential of the synthesized compounds to inhibit cell proliferation was studied on LNCaP, LAPC4 and PC-3 cell lines. All compounds were screened at $0.1,1,10$, and $20 \mu \mathrm{M}$ and the more active were chosen for $\mathrm{EC}_{50}$ calculation. The results are depicted in Table 2 and Fig. 2.

We identified compounds $13-15$ in the $2 \mathrm{H}$-indazole series that significantly inhibited the proliferation of LAPC4 and LNCaP cells mostly at 10 and $20 \mu \mathrm{M}$ (Fig. 2a and b), and were concomitanly effective against PC-3 cell proliferation. Their $\mathrm{EC}_{50}$ values for PC-3 cell proliferation were $5.4,8.3$, and $1.9 \mu \mathrm{M}$, respectively (Table 2). In the $1 \mathrm{H}$-indazole series, compound 10 was only active at $20 \mu \mathrm{M}$ for all PC cell lines. Compounds 11 and 12 were exclusively cytotoxic towards PC-3 cells, showing $50 \%$ inhibition of cell proliferation at 10 and $20 \mu \mathrm{M}$, respectively (Fig. 2c).

Thus, seeing that there is not a very high affinity of the compounds towards the AR, they probably act on PC cells through mechanisms other than the ones mediated by the AR such as apoptosis or cell cycle arrest. This is more evident for PC-3 cells that are human PC cells derived from bone metastases and do not express the AR at all.

In summary, the synthesized compounds were found not to inhibit $\mathrm{C}_{17,20}$-lyase activity significantly when compared to both ketoconazole and VN/85-1. They also did not display affinity towards the LNCaP mutated AR at the concentrations tested. Compounds 12 and 15 , having the $\Delta^{4}$-3-ketone system in common, bound to the wt-AR in the same extension as Casodex. However, only moderate inhibition of LAPC4 cell proliferation was seen with compound 15 at higher concentrations, suggesting that other mechanisms that are non-AR mediated account for this effect. The $2 \mathrm{H}$-indazole series (13-15) was particularly effective against PC-3 cells whereas compounds 11 and 12 of the $1 \mathrm{H}$-indazole series were exclusively toxic towards them. Because PC-3 cells lack the AR, it is likely that mechanisms such as apoptosis or cell cycle arrest account for inhibition of proliferation on this particular cell line.

\section{Acknowledgments}

Vânia M.A. Moreira thanks Fundação para a Ciência e a Tecnologia for supporting this work (BD/12508/2003). Jorge A.R. Salvador thanks Universidade de Coimbra for financial support.

Vânia M.A. Moreira and Jorge A.R. Salvador also thank Fundação Luso-Americana for sponsoring trips to the US that have strongly contributed to this work.

\section{REFERENCES}

[1] Nakajin S, Hall PF, Onoda M. Testicular microsomal cytochrome $\mathrm{P} 450$ for $\mathrm{C}_{21}$ steroid side chain cleavage. Spectral and binding studies. J Biol Chem 1981;256:6134-9.

[2] Nakajin S, Hall PF. Microsomal cytochrome P450 from neonatal pig testis. Purification and properties of a $\mathrm{C}_{21}$ steroid side-chain cleavage system ( $17 \alpha$-hydroxylase- $C_{17,20}$ lyase). J Biol Chem 1981;256:3871-6.

[3] Nakajin S, Shively JE, Yuan PM, Hall PF. Microsomal cytochrome $\mathrm{P} 450$ from neonatal pig testis: two enzymatic activities (17 $\alpha$-hydroxylase and $C_{17,20}$-lyase) associated with one protein. Biochemistry 1981;20:4037-42.

[4] Zuber MX, Simpson ER, Waterman MR. Expression of bovine $17 \alpha$-hydroxylase cytochrome P450 cDNA in nonsteroidogenic (COS 1) cells. Science 1986;234:1258-61.

[5] Hall PF. Cytochrome P450 $C_{21 s c c}$ : one enzyme with two actions: hydroxylase and lyase. J Steroid Biochem Mol Biol 1991;40:527-32.

[6] Denis LJ, Griffiths K. Endocrine treatment in prostate cancer. Semin Surg Oncol 2000;18:52-74.

[7] Chatterjee B. The role of the androgen receptor in the development of prostatic hyperplasia and prostate cancer. Mol Cell Biochem 2003;253:89-101.

[8] Huggins C, Hodges CV. Studies on prostatic cancer. I. The effect of castration, of estrogen and of androgen injection on serum phosphatases in metastatic carcinoma of the prostate. Cancer Res 1941;1:293-7.

[9] Huggins C, Stevens RE, Hodges CV. Studies on prostatic cancer. II. The effect of castration on clinical patients with carcinoma of the prostate. Arch Surg 1941;43:209.

[10] Resnick MI, Grayhack JT. Treatment of stage IV carcinoma of the prostate. Urol Clin North Am 1975;2:141-61, references cited therein.

[11] Koivisto P, Kolmer M, Visakorpi T, Kallioniemi OP. Androgen receptor gene and hormonal therapy failure of prostate cancer. Am J Pathol 1998;152:1-9, references cited therein.

[12] Chen CD, Welsbie DS, Tran C, Baek SH, Chen R, Vessella R, et al. Molecular determinants of resistance to antiandrogen therapy. Nat Med 2004;10:33-9.

[13] Debes JD, Tindall DJ. Mechanisms of androgen-refractory prostate cancer. N Engl J Med 2004;351:1488-90.

[14] Stanbrough M, Bubley GJ, Ross K, Golub TR, Rubin MA, Penning TM, et al. Increased expression of genes converting adrenal androgens to testosterone in androgen-independent prostate cancer. Cancer Res 2006;66:2815-25.

[15] Black RJ, Bray F, Ferlay J, Parkin DM. Cancer incidence and mortality in the European Union: cancer registry data and estimates of national incidence for 1990. Eur J Cancer 1997;33:1075-107.

[16] Greenlee RT, Murray T, Bolden S, Wingo PA. Cancer statistics, 2000. CA Cancer J Clin 2000;50:7-33.

[17] Jemal A, Siegel R, Ward E, Murray T, Xu J, Thun MJ. Cancer statistics, 2007. CA Cancer J Clin 2007;57:43-66. 
[18] Barrie SE, Jarman M. Inhibitors of cytochrome $\mathrm{P}^{4} 50_{17 \alpha}$ (17 $\alpha$-hydroxylase/ $\mathrm{C}_{17,20}$-lyase). Endocr Relat Cancer 1996;3:25-39.

[19] Jarman M, Smith HJ, Nicholls PJ, Simons C. Inhibitors of enzymes of androgen biosynthesis: cytochrome $\mathrm{P}^{4} 50_{17 \alpha}$ and 5 $\alpha$-steroid reductase. Nat Prod Rep 1998;15:495-512.

[20] Njar VC, Brodie AM. Inhibitors of $17 \alpha$-hydroxylase/17,20-lyase (CYP17): potential agents for the treatment of prostate cancer. Curr Pharm Des 1999;5:163-80.

[21] Hartmann RW, Ehmer PB, Haidar S, Hector M, Jose J, Klein $\mathrm{CD}$, et al. Inhibition of CYP 17, a new strategy for the treatment of prostate cancer. Arch Pharm Pharm Med Chem 2002;335:119-28.

[22] Leroux F. Inhibition of P450 17 as a new strategy for the treatment of prostate cancer. Curr Med Chem 2005;12:1623-9.

[23] Hakki T, Bernhardt R. CYP17- and CYP11B-dependent steroid hydroxylases as drug development targets. Pharmacol Ther 2006;111:27-52.

[24] Pont A, Williams PL, Azhar S, Reitz RE, Bochra C, Smith ER, et al. Ketoconazole blocks testosterone synthesis. Arch Intern Med 1982;142:2137-40.

[25] Santen RJ, Van den Bossche H, Symoens J, Brugmans J, De Coster R. Site of action of low dose ketoconazole on androgen biosynthesis in men. J Clin Endocrinol Metab 1983;57:732-6.

[26] Trachtenberg J, Pont A. Ketoconazole therapy for advanced prostate cancer. Lancet 1984;2:433-5.

[27] De Coster R, Caers I, Coene MC, Amery W, Beerens D, Haelterman C. Effects of high dose ketoconazole therapy on the main plasma testicular and adrenal steroids in previously untreated prostatic cancer patients. Clin Endocrinol 1986;24:657-64.

[28] Muscato JJ, Ahmann TA, Johnson KM, Wilding W, Monaghan G, Schlossman DM. Optimal dosing of ketoconazole (KETO) and hydrocortisone (HC) leads to long responses in hormone refractory prostate cancer. Proc Am Soc Clin Oncol 1994:13:229.

[29] Lake-Bakaar G, Scheuer PJ, Sherlock S. Hepatic reactions associated with ketoconazole in the United Kingdom. BM] 1987;294:419-22.

[30] Nakabayashi M, Xie W, Regan MM, Jackman DM, Kantoff PW, Oh WK. Response to low-dose ketoconazole and subsequent dose escalation to high-dose ketoconazole in patients with androgen-independent prostate cancer. Cancer 2006;107:975-81.

[31] Lam JS, Leppert JT, Vemulapalli SN, Shvarts O, Belldegrun AS. Secondary hormonal therapy for advanced prostate cancer. J Urol 2006;175:27-34.

[32] Potter GA, Barrie SE, Jarman M, Rowlands MG. Novel steroidal inhibitors of human cytochrome $\mathrm{P}^{4} 50_{17 \mathrm{a}}$ (17 $\alpha$-hydroxylase- $C_{17,20}$-lyase): potential agents for the treatment of prostatic cancer. J Med Chem 1995;38:2463-71.

[33] O'Donnell A, Judson I, Dowsett M, Raynaud F, Dearnaley D, Mason $\mathrm{M}$, et al. Hormonal impact of the $17 \alpha$-hydroxylase/ $C_{17,20}$-lyase inhibitor abiraterone acetate (CB7630) in patients with prostate cancer. Br J Cancer 2004;90:2317-25.

[34] Attard G, Belldegrun AS, De Bono JS. Selective blockade of androgenic steroid synthesis by novel lyase inhibitors as a therapeutic strategy for treating metastatic prostate cancer. BJU Int 2005;96:1241-6.

[35] Attard G, Reid AHM, Barrett M, Karavasilis V, Molife R, Thompson E, et al. Inhibition of androgen synthesis results in a high response rate in castration refractory prostate cancer. In: American association for cancer research annual meeting. 2007.
[36] Njar VC, Klus GT, Brodie AMH. Nucleophilic vinylic "addition-elimination" substitution reaction of $3 \beta$-acetoxy-17-chloro-16-formylandrosta-5,16-diene: a novel and general route to 17 -substituted steroids. Part 1. Synthesis of novel 17-azolyl- $\Delta^{16}$-steroids; inhibitors of $17 \alpha$-hydroxylase/17,20-lyase (17 $\alpha$-lyase). Bioorg Med Chem Lett 1996;6:2777-82.

[37] Njar VC, Kato K, Nnane IP, Grigoryev DN, Long BJ, Brodie AM. Novel 17-azolyl steroids, potent inhibitors of human cytochrome $17 \alpha$-hydroxylase- $\mathrm{C}_{17,20}$-lyase $\left(\mathrm{P}_{450} 0_{17 \alpha}\right)$ : potential agents for the treatment of prostate cancer. J Med Chem 1998;41:902-12.

[38] Handratta VD, Vasaitis TS, Njar VC, Gediya LK, Kataria R, Chopra P, et al. Novel C-17-heteroaryl steroidal CYP17 inhibitors/antiandrogens: synthesis, in vitro biological activity, pharmacokinetics, and antitumor activity in the LAPC4 human prostate cancer xenograft model. J Med Chem 2005;48:2972-84.

[39] Siddiqui AU, Rao VUM, Maimirani M, Siddiqui AH. Heterocyclic steroids: synthesis of androsteno[17,16-d]pyrazoles and androsteno[17,16-e]pyrimidines. J Heterocycl Chem 1995;32:353-4.

[40] Akhtar M, Corina DL, Miller SL, Shyadehi AZ, Wright JN. Incorporation of label from ${ }^{18} \mathrm{O}_{2}$ into acetate during side-chain cleavage catalyzed by cytochrome $\mathrm{P}^{4} 50_{17 \alpha}$ (17 $\alpha$-hydroxylase-17,20-lyase). J Chem Soc Perkin Trans I 1994:263-7.

[41] Grigoryev DN, Kato K, Njar VC, Long BJ, Ling YZ, Wang X, et al. Cytochrome P450c17-expressing Escherichia coli as a first-step screening system for $17 \alpha$-hydroxylase- $C_{17,20}$-lyase inhibitors. Anal Biochem 1999;267:319-30.

[42] Ling YZ, Li JS, Liu Y, Kato K, Klus GT, Brodie A. 17-Imidazolyl, pyrazolyl, and isoxazolyl androstene derivatives. Novel steroidal inhibitors of human cytochrome $\mathrm{C}_{17,20}$-lyase $\left(\mathrm{P}^{4} 0_{17 \alpha}\right)$. J Med Chem 1997;40:3297-304.

[43] Njar VC, Klus GT, Johnson HH, Brodie AM. Synthesis of novel 21-trifluoropregnane steroids: inhibitors of $17 \alpha$-hydroxylase/17,20-lyase (17 $\alpha$-lyase). Steroids 1997;62:468-73.

[44] Nnane IP, Kato K, Liu Y, Lu Q, Wang X, Ling YZ, et al. Effects of some novel inhibitors of $\mathrm{C}_{17,20}$-lyase and $5 \alpha$-reductase in vitro and in vivo and their potential role in the treatment of prostate cancer. Cancer Res 1998;58:3826-32.

[45] Grigoryev DN, Long BJ, Nnane IP, Njar VC, Liu Y, Brodie AM. Effects of new $17 \alpha$-hydroxylase/ $C_{17,20}$-lyase inhibitors on LNCaP prostate cancer cell growth in vitro and in vivo. $\mathrm{Br} \mathrm{J}$ Cancer 1999;81:622-30.

[46] Nnane IP, Kato K, Liu Y, Long BJ, Lu Q, Wang X, et al. Inhibition of androgen synthesis in human testicular and prostatic microsomes and in male rats by novel steroidal compounds. Endocrinology 1999;140:2891-7.

[47] Nnane IP, Njar VC, Liu Y, Lu Q Brodie AM. Effects of novel 17-azolyl compounds on androgen synthesis in vitro and in vivo. J Steroid Biochem Mol Biol 1999;71:145-52.

[48] Nnane IP, Long BJ, Ling YZ, Grigoryev DN, Brodie AM. Anti-tumour effects and pharmacokinetic profile of 17-(5'-isoxazolyl)androsta-4,16-dien-3-one (L-39) in mice: an inhibitor of androgen synthesis. Br J Cancer 2000;83:74-82.

[49] Zhu N, Ling Y, Lei X, Handratta V, Brodie AM. Novel $\mathrm{P}^{4} 50_{17 \alpha}$ inhibitors: 17-(2'-oxazolyl)- and 17-(2'-thiazolyl)-androstene derivatives. Steroids 2003;68:603-11.

[50] Wong C, Kelce WR, Sar M, Wilson EM. Androgen receptor antagonist versus agonist activities of the fungicide vinclozolin relative to hydroxyflutamide. J Biol Chem 1995;270:19998-20003.

[51] Yarbrough WG, Quarmby VE, Simental JA, Joseph DR, Sar M, Lubahn DB, et al. A single base mutation in the androgen 
receptor gene causes androgen insensitivity in the testicular feminized rat. J Biol Chem 1990;265:8893-900.

[52] Meyer MD, Kruse LI. Ergoline synthons: synthesis of 3,4-dihydro-6-methoxybenz[cd]indol-5(1H)-one (6-methoxy-Uhle's ketone) and 3,4-dihydrobenz[cd]indol-5(1H)-one (Uhle's ketone) via a novel decarboxylation of indole-2-carboxylates. J Org Chem 1984;49:3195-9.
[53] Begtrup M, Elguero J, Faure R, Camps P, Estopa C, Ilavsky D, et al. NMR studies in the heterocyclic series. Part 31. Effect of $\mathrm{N}$-substituents on the ${ }^{13} \mathrm{C}$ NMR parameters of azoles. Magn Reson Chem 1988;26:134-51.

[54] Long BJ, Grigoryev DN, Nnane IP, Liu Y, Ling YZ, Brodie AM. Antiandrogenic effects of novel androgen synthesis inhibitors on hormone-dependent prostate cancer. Cancer Res 2000;60:6630-40. 